Published by LPMP Imperium

Journal homepage: https:/ / ejournal.imperiuminstitute.org/ index.php/ AKURASI

\title{
ANALISIS PENGARUH GOOD CORPORATE GOVERNANCE TERHADAP KINERJA KEUANGAN BANK UMUM SYARIAH
}

\author{
Indriyani*, Rinda Asytuti \\ Jurusan Ekonomi Syariah Fakultas Ekonomi dan Bisnis Islam \\ Institut Agama Islam Negeri Pekalongan
}

\begin{abstract}
This study aims to determine the effect of Good Corporate Governance on Islamic banking financial performance as measured by Return On Assets. Good Corporate The governance used in this study is Board of Commissioners size, board size, audit committee size, sharia supervisory board size and Islamic social reporting. The population in this study is all Sharia Commercial Banks in Indonesia. In this study the sample used was 9 Islamic commercial banks from 2015-2018. The data analysis technique used is multiple linear regression test. The results showed that the size of the board of commissioners and ISR partially had a significant negative effect on ROA. While the size of the board of directors, the size of the audit committee and the size of the sharia supervisory board have no significant effect on ROA.
\end{abstract}

\begin{abstract}
Abstrak
Penelitian ini bertujuan untuk mengetahui pengaruh Good Corporate Governance terhadap kinerja keuangan perbankan syariah yang diukur dengan Return On Assets. Good Corporate Governance yang digunakan dalam penelitian ini yaitu Ukuran Dewan komisaris, ukuran dewan direksi, ukuran komite audit, ukuran dewan pengawas syariah dan Islamic social reporting. Populasi dalam penelitian adalah seluruh Bank Umum Syariah di Indonesia. Dalam penelitian ini sampel yang digunakan adalah 9 bank umum syariah dari tahun 2015-2018. Teknik analisis data yang digunakan adalah uji regresi linier berganda. Hasil penelitian menunjukkan ukuran dewan komisaris dan ISR secara parsial berpengaruh negatif signifikan terhadap ROA. Sedangkan ukuran dewan direksi, ukuran komite audit dan ukuran dewan pengawas syariah tidak berpengaruh signifikan terhadap ROA.
\end{abstract}

$\triangle$ Email korespondensi: Indriani.indun@gmail.com

Pedoman Sitasi: Indriyani. I, \& Asyuti, R. (2019). ANALISIS PENGARUH GOOD CORPORATE GOVERNANCE TERHADAP KINERJA KEUANGAN BANK UMUM SYARIAH. AKURASI: Jurnal Riset Akuntansi dan Keuangan, 1(2), 111120

DOI: https:// doi.org/ 10.36407/ akurasi.v1i2.117

\section{AKURASI}

\section{1}

Paper type

Research paper

Received: 07 Dec 2019

Accepted: 26 Dec 2019

Online: 30 Dec 2019

Keywords: GCG, Return on Asset, Islamic Bank

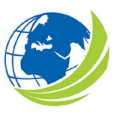

Akurasi: Jurnal Riset Akuntansi dan Keuangan, Vol 1, No.2, Desember 2019, pp. 111-120 eISSN: 2685-2888 


\section{PENDAHULUAN}

Berbagai isu yang berhubungan dengan Corporate Governance menjadi populer di Indonesia di penghujung abad ke-20, tepatnya setelah terjadinya krisis ekonomi dalam di tahun 1997 dan krisis financial global di tahun 2008. Isu ini semakin menguat kembali setelah bangkrutnya beberapa perusahaan-perusahaan ternama seperti Enron dan WorldCom di Amerika Serikat. Salah satu penyebab krisis Asia pada tahun 1998 juga diduga karena kegagalan implementasi GCG untuk yang kemudian memicu fundamental ekonomi makro menjadi sangat rapuh (Siswanti et al., 2017). Krisis telah membangkitkan pentingnya perlindungan investor dan praktik Tata Kelola Perusahaan yang Baik (Cabalu, 2005 dalam Hamsyi, 2019). Dengan mekanisme dan pengawasan GCG, inefisiensi karena moral hazard dan pemilihan yang merugikan dapat diminimalisir. Begitu juga yang terjadi di Indonesia, banyak perusahaan bangkrut yang diindikasi sebagai akibat belum menerapkan prinsip-prinsip GCG, disamping banyaknya praktik korupsi, kolusi, dan nepotisme yang terjadi di perusahaan global (Ali, 2013).

Sejak terjadinya krisis finansial global di tahun 2008, para praktisi dan akademisi mulai banyak tertarik pada sistem keuangan alternative yang didasarkan pada ekonomi Islam. Sebagai lembaga keuangan berbasis Islam, perbankan syariah sebagai lembaga dengan aransemen profit and loss sharing dimana dalam semua aktivitasnya harus mentaati hukum syariah. Penerapan good corporate governance di lembaga perbankan syariah menjadi sebuah keharusan, bahkan bank-bank syariah harus tampil sebagai pionir terdepan dalam mengimplementasikan GCG tersebut. Disamping itu, implementasi GCG pada lembaga perbankan khususnya perbankan syariah menjadi sebuah keharusan karena aset fisik dari bank adalah nasabahnya, sehingga bank harus menjaga kepercayaan nasabahnya bahwa dana yang tersimpan akan dikelola dengan baik dan aman. Kepercayaan tersebut bisa tetap terjaga apabila bank dalam kondisi yang sehat. Kondisi perbankan yang sehat dapat tercapai apabila bank memiliki sistem yang baik, sehingga bank dapat melayani nasabah semaksimal mungkin dalam kondisi yang sehat (Agus, 2018).

Dalam rangka meningkatkan kinerja bank, melindungi kepentingan para pemangku kepentingan, dan meningkatkan kepatuhan terhadap peraturan perundang-undangan serta nilai-nilai etika (code of conduct) yang berlaku secara umum pada industri perbankan, bank wajib melaksanakan kegiatan usahanya dengan berpedoman pada prinsip prinsip tata kelola yang baik. Pelaksanaan tata kelola pada industri perbankan harus senantiasa berlandaskan pada 5 (lima) prinsip dasar. Pertama, tranparansi (transparency), Kedua akuntabilitas (accountability), Ketiga pertanggungjawaban (responsibility), Keempat independensi (independency), Kelima kewajaran (fairness). Dalam rangka menerapkan kelima prinsip dasar tersebut, Bank wajib berpedoman pada berbagai ketentuan dan persyaratan minimum serta pedoman yang terkait dengan pelaksanaan tata kelola (POJK, 2016)

Pada tahun 2017 Majalah Ekonomic Review menyelenggarakan Indonesia Good Corporate Governance Award III 2017 sebagai ajang penghargaan bagi perusahaan terbaik di bidang GCG dengan standar penilaian yang obyektif dan fair oleh dewan juri independen di bidang GCG. Penilaian penghargaan ini dilakukan melalui beberapa indikator penilaian yaitu laporan keuangan audited perusahaan (25\%), laporan tahunan perusahaan (40\%), kelengkapan infrastructure GCG (20\%), kelengkapan soft structure GCG (10\%) serta keterbukaan atas masalah yang dihadapi perusahaan. Terdapat 67 perusahaan terbaik dalam bidang GCG termasuk Bank Tbk dan Bank Syariah non Tbk sebagai berikut: 
AKURASI, 1(2), 99-108

Indriyani \& Asytuti, R. GCG dan ROA perbankan syariah....

Tabel 1. Penerima IGCGA-III-2017 (Bank - TBK)

\begin{tabular}{|c|l|c|}
\hline No & \multicolumn{1}{|c|}{ Bank - TBK } & Peringkat \\
\hline 1 & PT. Bank Jatim, Tbk & 2 \\
\hline 2 & PT. Bank Bukopin, Tbk & 3 \\
\hline 3 & PT. Bank BTPN Tbk & 4 \\
\hline 4 & PT. Bank Artha Graha Internasional, Tbk & 5 \\
\hline 5 & PT. Bank Sinarmas, Tbk & 6 \\
\hline 6 & PT. Bank Mayapada Internasional, Tbk & 8 \\
\hline 7 & PT. Bank Panin Dubai Syariah, Tbk & 9 \\
\hline 8 & PT. Bank Muamalat Indonesia, Tbk & 7 \\
\hline 9 & PT. Bank Maspion Indonesia, Tbk & \multicolumn{1}{|c|}{ Tbk } \\
\hline
\end{tabular}

Sumber: Majalah Ekonomic Review, 2017

Pada Tabel 1 dapat dilihat bahwa Bank Syariah go public menempati posisi IGCGA 2017 dibawah bank kovensional, pada posisi ke 7 yaitu PT. Bank Panin Dubai Syariah, Tbk dan posisi ke 8 PT. Bank Muamalat Indonesia, Tbk

Tabel 2. Penerima IGCGA-III-2017Bank Syariah - Non TBK

\begin{tabular}{|c|l|c|}
\hline No & \multicolumn{1}{|c|}{ Bank Syariah - Non TBK } & Peringkat \\
\hline 1 & PT. BNI Syariah & 1 \\
\hline 2 & PT. Bank Syariah Bukopin & 2 \\
\hline 3 & PT. BCA Syariah & 3 \\
\hline 4 & PT. BTPN Syariah & 4 \\
\hline
\end{tabular}

Sumber: Majalah Ekonomic Review, 2017

Dari Tabel 2 terlihat bahwa dimana Bank Syariah non Tbk hanya menyumbangkan 4 Perbankan dari total 11 bank syariah non Tbk yaitu PT. BNI Syariah, PT. Bank Syariah Bukopin, PT. BCA Syariah dan PT. BTPN Syariah. Dari uraian diatas dapat disimpulkan bahwa penerapan Good Corporate Governance pada industri perbankan syariah masih tergolong lemah, padahal dengan menerapkan Good Corporate Governance dengan baik dapat meminimalisir fraud, meningkatkan kinerja perusahaan, menarik investor untuk menanamkan modal dan dapat membuat perusahaan di indonesia makin kompetitif di ASEAN. Penerapan GCG juga diharapkan dapat menjaga profitabilitas yang berkelanjutan.

Studi mengenai pengaruh GCG terhadap profitabilitas di sektor perbankan syariah seperti Siswanti et al. (2017); Ghalib (2018); Nurkhin et al. (2018) yang mendukung GCG sebagai faktor yang mempengaruhi profitabilitas perbankan syariah. Penelitian lainnya dilakukan oleh Mayur dan Saravanan (2017) meneliti implikasi kinerja ukuran dewan, komposisi dewan, dan frekuensi pertemuan dewan untuk kinerja bank. Hubungan curvilinear ditemukan antara ukuran dewan dan kinerja bank. Namun penelitian terbaru yang dilakukan oleh Hamsyi (2019); Pratiwi dan Nugraha (2016) dan Umanto et al. (2016) menyimpulkan bahwa tidak ada dampak yang signifikan GCG terhadap kinerja keuangan perbankan syariah. Penelitian ini bertujuan untuk berkontribusi pada literatur yang ada tentang dampak GCG pada kinerja bank menggunakan kasus Indonesia.. Didasarkan masih adanya kesenjangan penelitian mengenai peran GCG dalam mempengaruhi profitabilitas maka penelitian ini ditujukan untuk 
melakukan klarifikasi ulang dengan mengambil sampel Sembilan bank umum syariah. Penelitian ini akan memperluas studi tempiris tentang tata kelola dan kinerja bank syariah di Indonesia.

\section{KAJIAN PUSTAKA}

Kinerja perusahaan dapat dinilai melalui berbagai macam indikator atau variable untuk mengukur keberhasilan perusahaan, pada umumnya berfokus pada informasi kinerja yang berasal dari laporan keuangan. Laporan keuangan tersebut bermanfaat bagi para pengguna laporan keuangan dalam rangka membuat keputusan investasi, penempatan dana, pembiayaan, serta prospek bank syariah dimasa mendatang Return on Asset (ROA) merupakan rasio untuk mengetahui tingkat profitabilas perbankan syariah yang diukur dengan membandingkan antara laba sebelum pajak dengan total aset bank syariah. Dengan demikian emakin tinggi rasio ini maka kemampuan bank dalam memperoleh keungantungan semakin bank. Formula untuk mengetahui rasio ini adalah ROA = Earning After Taxes / Total Assets (Pudail, 2018).

Konsep GCG adalah sesuatu yang harus diterapkan untuk membangun kondisi perusahaan yang kuat, termasuk di perbankan syariah. Perlunya penerapan GCG di bank syariah ditandai sejak adanya Peraturan Bank Indonesia (PBI) No. 8 / S4 / PBI / 2006 tentang penerapan GCG di perbankan, termasuk perbankan Syariah. Kemudian diganti dengan PBI No. 11/33 / PBI / 2009 tentang penerapan GCG untuk Bank Umum Syariah dan Unit Bisnis Syariah, mengingat bahwa GCG yang akan diterapkan pada perbankan Syariah harus mematuhi prinsip-prinsip Syariah (Hamsyi, 2019). Dalam penelitian ini, GCG di proksi-kan dengan lima indikator meliputi dewan komisaris, dewan direksi, komite audit, dewan pengawas syariah, dan Islamic social reporting.

Dewan komisaris adalah organ emiten atau perusahaan publik yang bertugas melakukan pengawasan secara umum dan/atau khusus sesuai dengan anggaran dasar serta memberi nasihat kepada direksi, Jumlah anggota dewan Komisaris paling sedikit 3 (tiga) orang dan paling banyak sama dengan jumlah anggota direksi (POJK, 2014).

Direksi adalah organ emiten atau perusahaan publik yang berwenang dan bertanggung jawab penuh atas pengurusan emiten atau perusahaan publik untuk kepentingan emiten atau perusahaan publik, sesuai dengan maksud dan tujuan emiten atau perusahaan publik serta mewakili emiten atau perusahaan publik, baik di dalam maupun di luar pengadilan sesuai dengan ketentuan anggaran dasar. Jumlah anggota direksi paling kurang 3 (tiga) orang (POJK, 2014). Dewan komisaris sebagai salah satu mekanisme good corporate governance bertanggung jawab mengawasi proses pelaporan keuangan dan menilai kualitas tata kelola perusahaan. Semakin tinggi jumlah dewan komisaris maka dapat meningkatkan fungsi pengawasan dalam pengelolaan perusahaan dan mengurangi konflik keagenan yang terjadi diantara principal dan agent sehingga kinerja perusahaan dapat meningkat. Kinerja perusahaan yang meningkat ditandai dengan meningkatnya profitabilitas dalam perusahaan (Ramiyati, 2016).

Komite audit adalah komite yang dibentuk oleh dan bertanggung jawab kepada dewan komisaris dalam membantu melaksanakan tugas dan fungsi dewan komisaris (POJK, 2015). Anggota komite audit paling sedikit berjumlah 3 orang yaitu terdiri dari seorang komisaris independen, seorang pihak independen yang ahli di bidang akuntansi keuangan, dan seorang pihak independen yangahli di bidang perbankan syariah (POJK, 2016). Komite audit berfungsi untuk melaksanakan pengawasan internal perusahaan atas pelaksanaan audit, manajemen risiko, proses pelaporan keuangan, dan implementasi Corporate Governance di perusahaan. Pengawasan yang dilaksanakan oleh komite audit diharapkan dapat meningkatan kinerja keuangan perusahaan (Amelya, 2019). 
Dewan pengawas syariah adalah dewan yang bertugas memberikan nasihat dan saran kepada direksi serta mengawasi kegiatan bank agar sesuai dengan prinsip syariah (POJK, 2017). Jumlah anggota dewan pengawas syariah sekurang-kurangnya 2 orang dan sebanyak-banyaknya 5 orang. Menurut Chtourou, dkk dalam Dewayanto menyatakan bahwajumlah dewan yang semakin besar maka mekanisme monitoring manajemen perusahaan akan semakin baik. Dengan demikian, semakin besar jumlah anggota dewan pengawas syariah maka akan meningkatkan pengawasan terhadap pengelolaan bank yang sesuai dengan prinsip syariah, sehingga tidak terjadi penggunaan dana yang tidak berprinsip syariah yang dapat mengurangi profitabilitas. Dengan demikian, profitabilitas bank akan meningkat

Indeks ISR adalah poin-poin pengungkapan yang digunakan sebagai indikator dalam pelaporan kinerja sosial institusi bisnis syariah. Pada awal pembentukannya, indeks ISR hanya berisikan lima tema yang di kembangkan dalam penelitian Haniffa (2006) dalam pengungkapan Indeks ISR, yaitu tema pembiayaan dan investasi, tema produk dan jasa, tema karyawan, tema masyarakat, dan tema lingkungan. Islamic social reporting (ISR) merupakan kegiatan non-financial yang membutuhkan dana yang besar untuk melaksanakannya. Sesuai dengan Peraturan Menteri BUMN No. 4 Tahun 2007 bahwa dana pengungkapan tanggung jawab sosial perusahaan diambil 2\% laba bersih. Jika pengungkapan informasi sosial yang dilakukan oleh perusahaan semakin banyak maka dapat meningkatkan kinerja keuangan perusahaan (Iwan, et al., 2018)

\section{METODE PENELITIAN}

Desain Penelitian

Metode analisis data pada penelitian ini yaitu menggunakan analisis data kuantitatif model deskriptif, dengan melakukan perhitungan-perhitungan terhadap data keuangan yang diperoleh untuk memecahkan masalah yang ada sesuai dengan tujuan penelitian. Metode analisis data yang digunakan dalam penelitian ini adalah dengan menggunakan analisis statistik deskriptif dan inferensi menggunakan software SPSS 20.

\section{Prosedur Sampel}

Populasi pada penelitian ini yaitu annual report Bank Umum Syariah tahun 2015-2018. Sampel pada penelitian ini yaitu Bank Umum Syariah yang ada di Indonesia dari tahun 2015-2018. Teknik pengambilan sampel yang digunakan dalam penelitian ini dengan metode purposive sampling yang menghasilan 9 sampel untuk penelitian ini yaitu BMI, BRIS, BNIS, BSM, BMS, BPDS, BSB, BCAS, dan BTPNS.

Pengukuran variabel

Dewan komisaris adalah organ emiten atau perusahaan publik yang bertugas melakukan pengawasan secara umum dan/atau khusus sesuai dengan anggaran dasar serta memberi nasihat 
kepada direksi, Jumlah anggota dewan Komisaris paling sedikit 3 (tiga) orang dan paling banyak sama dengan jumlah anggota direksi (POJK, 2014).

Direksi adalah organ emiten atau perusahaan publik yang berwenang dan bertanggung jawab penuh atas pengurusan emiten atau perusahaan publik untuk kepentingan emiten atau perusahaan publik, sesuai dengan maksud dan tujuan emiten atau perusahaan publik serta mewakili emiten atau perusahaan publik, baik di dalam maupun di luar pengadilan sesuai dengan ketentuan anggaran dasar. Jumlah anggota direksi paling kurang 3 (tiga) orang (POJK, 2014). Komite audit adalah komite yang dibentuk oleh dan bertanggung jawab kepada dewan komisaris dalam membantu melaksanakan tugas dan fungsi dewan komisaris (POJK, 2015).

Dewan pengawas syariah adalah dewan yang bertugas memberikan nasihat dan saran kepada direksi serta mengawasi kegiatan bank agar sesuai dengan prinsip syariah (POJK, 2017). Indeks ISR adalah poin-poin pengungkapan yang digunakan sebagai indikator dalam pelaporan kinerja sosial institusi bisnis syariah.

Teknik Analisis Data

Alat analisis yang digunakan pada penelitian ini yaitu dengan menggunakan analisis deskriptif dan regresi linear berganda.

\section{HASIL DAN PEMBAHASAN}

Analisis deskriptif

Variabel ukuran dewan komisaris memiliki nilai rata-rata atau mean sebesar 3,8611. Nilai maksimum sebesar 6,00. Nilai minimum sebesar 3,00 dan nilai standar deviasi sebesar 0,79831. Variabel ukuran dewan direksi memiliki nilai rata-rata atau mean sebesar 4,4167. Nilai maksimum sebesar 7,00. Nilai minimum sebesar 3,00 dan nilai standar deviasi sebesar 1,22766.

Variabel ukuran ukuran komite audit memiliki nilai rata-rata atau mean sebesar 4,0000. Nilai maksimum sebesar 7,00. Nilai minimum sebesar 2,00 dan nilai standar deviasi sebesar 1,19523. Variabel ukuran DPS memiliki nilai rata-rata atau mean sebesar 2,3333. Nilai maksimum sebesar 3,00. Nilai minimum sebesar 2,00 dan nilai standar deviasi sebesar ,47809. Variabel ISR memiliki nilai rata-rata atau mean sebesar 0,7097. Nilai maksimum sebesar 0,83. Nilai minimum sebesar 0,46 dan nilai standar deviasi sebesar 0,10410. Variabel Dependen dalam penelitian ini adalah Return On Assets (ROA). ROA adalah rasio yang mengukur seberapa efisien suatu perusahaan dalam mengelola asetnya untuk menghasilkan laba dalam satu periode. ROA memiliki nilai rata-rata sebesar 0,013875. Nilai maksimal sebesar 0,1240. Nilai minimal sebesar -0,1077 dan nilai stansar deviasi sebesar 0,0364414 .

\section{Analisis regresi}

Uji Koefisien Determinasi (R2) sebesar 0,332, hal ini menunjukkan bahwa variabel-variabel independen (ukuran dewan komisaris, ukuran dewan direksi, ukuran komite audit, ukuran DPS dan ISR) sebesar 33\% variasi yang berpengaruh terhadap variabel dependen (Return On Assets) sedangkan sisanya $(100 \%-33 \%)=67 \%$ dijelaskan oleh variabel-variabel lain diluar model yang tidak dijelaskan dalam penelitian ini. Berdasarkan hasil dari uji Anova atau F test pada tabel 4.7 bahwa nilai signifikansi 0,004, nilai Fhitung sebesar 4,487 dan nilai $F$ tabel sebesar 2,53 degan nilai signifikansi 0,004 < 0.05 sehingga dapat disimpulkan bahwa kelima variabel yaitu ukuran dewan komisaris, ukuran dewan direksi, ukuran komite audit, ukuran dewan pengawas syariah dan islamic social reporting berpengaruh positif dan signifikan tehadap nilai variabel ROA Bank Umum Syariah tahun 2015-2018.

Uji regresi linier berganda digunakan untuk mengetahui seberapa besar pengaruh variabel independen (X1, X2, X3, X4 dan X5) terhadap variabel dependen (ROA). Berdasarkan analisis data 
AKURASI, 1(2), 99-108

Indriyani \& Asytuti, R. GCG dan ROA perbankan syariah....

uji linier berganda maka diperoleh hasil persamaan regresi sebagai berikut:

$\mathrm{Y}=0,107-0,16 \mathrm{X} 1+0,007 \mathrm{X} 2+0,006 \mathrm{X} 3+0,013 \mathrm{X} 4-0,167 \mathrm{X} 5$

Tingkat signifikasi variabel ukuran dewan komisaris (X1) adalah 0,040 dan nilai thitung =2,145 dengan arah yang negatif. Nilai thitung lebih besar dari ttabel yaitu 2,042. Begitu pula dengan tingkat signifikansinya lebih kecil dari taraf signifikan 0,05 . Ukuran dewan komisaris berpengaruh negarif dan signifikan terhadap ROA Bank Umum Syariah.

Tingkat signifikasi variabel ukuran dewan direksi (X2) adalah 0,201 dan nilai thitung = 1,308 dengan arah yang positif. Nilai thitung 1,308 lebih kecil dari ttabel yaitu 2,042. Begitu pula dengan nilai sig lebih besar dari 0,05. Dengan demikian secara parsial hipotesis 2 teruji bahwa ukuran dewan direksi tidak berpengaruh signifikan terhadap ROA Bank Umum Syariah.

Tingkat signifikasi variabel ukuran komite audit (X3) adalah 0,167 dan nilai thitung $=1,416$ dengan arah yang positif. Nilai thitung 1,416 lebih kecil dari ttabel yaitu 2,042. Begitu pula dengan nilai sig lebih besar dari 0,05. Dengan demikian secara parsial hipotesis 3 teruji bahwa ukuran komite audit tidak berpengaruh signifikan terhadap ROA Bank Umum Syariah.

Tingkat signifikasi variabel ukuran DPS (X4) adalah 0,326 dan nilai thitung $=1,000$ dengan arah yang positif. Nilai thitung 1,000 lebih kecil dari t-tabel yaitu 2,042. Begitu pula dengan nilai sig lebih besar dari 0,05. Dengan demikian secara parsial hipotesis 4 teruji bahwa ukuran DPS tidak berpengaruh signifikan terhadap ROA Bank Umum Syariah. Tingkat signifikasi variabel ISR adalah 0,005 dan nilai thitung $=3,007$ dengan arah yang negatif. Nilai $t$ hitung lebih besar dari $t$-tabel yaitu 2,042. Begitu pula dengan tingkat signifikansinya lebih kecil dari taraf signifikan 0,05. Dengan demikian secara parsial hipotesis 5 teruji bahwa ISR berpengaruh negatif dan signifikan terhadap ROA Bank Umum Syariah. Berarti semakin meningkat ISR maka akan menurunkan nilai ROA.

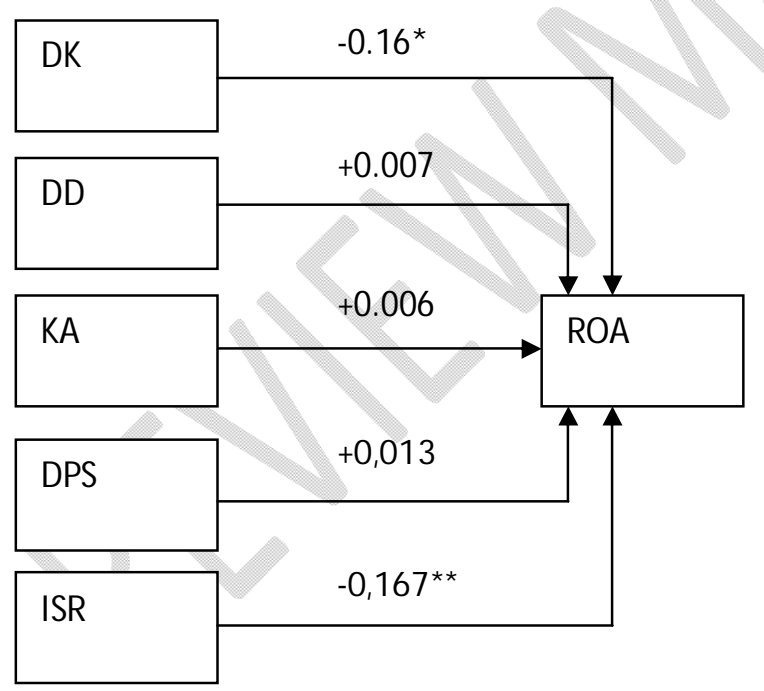

Keterangan: * signifikan di level 5\%; **signifikan di level 1\%; tidak bertanda =tidak signifikan $\mathrm{DK}=$ dewan komisaris; $\mathrm{DD}=$ dewan direksi; $\mathrm{KA}=$ komite audit; $\mathrm{DPS}=$ dewan pengawas syariah; ISR=Islamic Social Reporting

Secara umum hasil penelitian memperlihatkan bahwa dari lima indikator GCG tidak seluruhnya yang memiliki efek signifikan terhadap profitabilitas. Hasil ini mempertegas bahwa studi GCG dan dampaknya pada kinerja keuangan perbankan syariah memang dapat berbeda seperti penelitian sebelumnya. Disatu 
sisi, penelitian ini sejalan dengan Siswanti et al. (2017); Ghalib (2018); Nurkhin et al. (2018) yang mendukung GCG sebagai faktor yang mempengaruhi profitabilitas perbankan syariah, namun disisi lain juga mendukung Hamsyi (2019); Pratiwi dan Nugraha (2016) dan Umanto et al. (2016) menyimpulkan bahwa tidak ada dampak yang signifikan GCG terhadap kinerja keuangan perbankan syariah. Dua komponen GCG yang menjadi determinan profitabilitas perbankan syariah adalah Dewan Komisaris dan Islamic Social Reporting (ISR) sehingga dua factor ini perlu mendapatkan perhatian selanjutnya dari pihak perbankan syariah maupun peneliti yang mengkaji hal serupa.

\section{KESIMPULAN}

Kesimpulan

Berdasarkan hasil penelitian dapat disimpulkan bahwa ukuran dewan komisaris berpengaruh negatif dan signifikan terhadap Return On Asset, ukuran dewan direksi tidak berpengaruh signifikan terhadap ROA, ukuran komite audit tidak berpengaruh signifikan terhadap ROA, ukuran dewan pengawas syariah tidak berpengaruh signifikan terhadap ROA dan islamic social reporting berpengaruh negatif dan signifikan terhadap ROA. Dengan demikian hanya ukuran dewan komisaris dan islamic social reporting yang terbukti memiliki efek terhadap ROA perbankan syariah.

Implikasi Praktis

Berdasarkan kesimpulan yang sudah dijelaskan sebelumnya, maka implikasi temuan ini adalah pihak perbankan disarankan untuk memperhatikan ukuran dewan komisaris dengan mengacu pada peraturan OJK adalah jumlah anggota dewan Komisaris paling sedikit 3 (tiga) orang dan paling banyak sama dengan jumlah anggota direksi (POJK, 2014). Berikutya terkait dengan islamic social reporting, pihak perbankan perlu mempertimbangkan untuk menggunakan indeks ISR yang terdiri dari 6 tema, yaitu pembiayaan dan investasi, tema produk dan jasa, tema karyawan, tema masyarakat, dan tema lingkungan dan pengungkapan tata kelola perusahaan.

Keterbatasan dan Saran

Penelitian ini terbatas pada periode pengamatan yaitu dari 2015 - 2018 sehingga memiliki kemungkinan keterbatasan dalam generalisasi. Meskipun data yang digunakan sudah memenuhi asumsi klasik, namun riset berikutnya disarankan untuk memperluas cakupan periode pengamatan. Selain itu, perlu mempertimbangkan untuk membandingkan hasil studi pada bank umum syariah dengan unit usaha syariah untuk memberikan gambaran menyeluruh mengenai lembaga keuangan syariah.

\section{REFERENSI}

Ghalib, S. (2018). Good Corporate Governance Rating And Bank Profitability In Indonesia: Evidence From Panel Data. International Journal of Business \& Society, 19(3).

Hamsyi, N. F. (2019). The impact of good corporate governance and Sharia compliance on the profitability of Indonesia's Sharia banks. Problems and Perspectives in Management, 17(1), 56.

Haniffa, R., \&Hudaib, M. (2006). Corporate Governance Structure and Performance of Malaysian Listed Companies. Journal of Business Finance \& Accounting,33(7-8),1034-1062

Mayur, M., \& Saravanan, P.(2017). Performance implications of board size, composition and activity: Empirical evidence from the Indian banking sector.Corporate Governance (Bingley),17(3), 466489

Nurkhin, A., Rohman, A., Rofiq, A., \& Mukhibad, H. (2018). The role of the Sharia Supervisory Board and corporate governance mechanisms in enhancing Islamic performance-evidence from Indonesia. Banks and Bank Systems, 13(4), 85.

Pratiwi, N. A., \&Nugraha, A. P. (2016). Risk profile, good corporate governance, earnings, capital (Bank Mandiri, 2011-2013).JurnalIlmiah FEB,3(2). 
AKURASI, 1(2), 99-108

Indriyani \& Asytuti, R. GCG dan ROA perbankan syariah....

Pudail, M., Fitriyani, Y., \& Labib, A. (2018). Good Corporate Governance dalam Meningkatkan Kinerja Keuangan Bank Syariah. Wahana Islamika: Jurnal Studi Keislaman, 4(1), 127-149.

Santoso.(2017). FSA: GCG Practice among firms in Indonesia are left behind (OJK: Praktik GCG Perusahaan Indonesia Masih Tertinggal), CNN Indonesia, Wednesday, 20/ 09/ 2017:08:51

Setiawan, I., Swandari, F., \& Dewi, D. M. (2019). Pengaruh Pengungkapan Islamic Social Reporting (Isr) Terhadap Nilai Perusahaan Dengan Kinerja Keuangan Sebagai Variabel Moderating. Jurnal Wawasan Manajemen, 6(2), 168-186.

Siswanti, I., Salim, U., Sukoharsono, E. G., \& Aisjah, S. (2017). The Impact of Islamic Corporate Governance, Islamic Intellectual Capital and Islamic Financial Performance on Sustainable Business Islamic Banks. International Journal of Economics and Financial Issues, 7(4), 316-323.

Umanto, U., Wijaya, C., \&Atmoko, A. W. (2016). Corporate Governance with the Institutional Theory Approach on Regional Development Banks in Indonesia.BISNIS \& BIROKRASI: Jurnalllmu Administrasi dan Organisasi,22(2), 100-110.

Peraturan Otoritas Jasa Keuangan No. 33/ POJK.04/ 2014

Peraturan Otoritas Jasa Keuangan NO. 55 / POJK.04/ 2015

Peraturan Otoritas Jasa Keuangan, Nomor 55/ POJK.03/ 2016

Peraturan Otoritas Jasa Keuangan NO. 59 / POJK.03/ 2017

Peraturan Otoritas Jasa Keuangan, Nomor 55/ POJK.03/ 2016

Peraturan Otoritas Jasa Keuangan No. 33/ POJK.04/ 2014

Peraturan Otoritas Jasa Keuangan No. 55/ POJK.03/ 2016

\section{PROFIL PENULIS}

Indriyani dan Rinda Asytuti adalah mahasiswa dan dosen di Jurusan Ekonomi Syariah Fakultas Ekonomi dan Bisnis Islam Institut Agama Islam Negeri Pekalongan 
AKURASI: Jurnal Riset Akuntansi dan Keuangan

Vol 1, No. 2, December 2019

Published by LPMP Imperium

AKURASI: Jurnal Riset Akuntansi dan Keuangan

Akurasi:Jurnal Riset Akuntansi dan Keuangan, Vol 1, No.2, Desember 2019, pp. 111-120

eISSN: $2685-2888$

Journal homepage: https:// ejournal.imperiuminstitute.org/ index.php/AKURASI 